\title{
Accumulation and Degradation of Thiabendazole Residues in Eggs in Administered Layer Hens
}

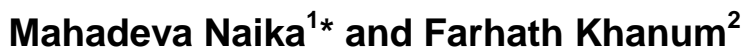 \\ ${ }^{1}$ Applied Nutrition Division, Defence Food Research Laboratory, Siddarthanagar, Mysore-570011, India \\ ${ }^{2}$ Biochemistry and Nano Sciences, Defence Food Research Laboratory, Siddarthanagar, Mysore-570011, \\ India
}

\begin{tabular}{|c|c|}
\hline \multirow{14}{*}{$\begin{array}{l}\text { Abstract } \\
\text { Administration of thiabendazole (TBZ) to laying hens may cause accumulation of the drug } \\
\text { residues in eggs. Twenty five week old hens }(\mathrm{n}=6) \text { were administered with a single oral dose } \\
\text { of } 75 \mathrm{mg} \text { TBZ/day/layer hen for } 5 \text { consecutive days and its residues in eggs were quantified } \\
\text { by HPLC-FD. The highest TBZ }(0.4308 \pm 0.0253 \mathrm{ppm}) \text {, below maximum residue limit } \\
(0.0886 \pm 0.0161 \mathrm{ppm}) \text { and below limit of detection }(\mathrm{LOD}) \text { residue concentrations in eggs were } \\
\text { observed on mean time of } 127.54,177.62 \text { and } 252.58 \mathrm{~h} \text { after first feeding, respectively. The } \\
\text { highest TBZ concentration }(0.5260 \mathrm{ppm}) \text { and total residue on any day from } 2 \text { to } 9 \text { day in the } \\
\text { entire egg white portion were significantly }(P<0.01) \text { higher than those in the yolk. The highest } \\
\text { residue concentrations as well as the highest total residue in egg albumin }(0.5944 \text { ppm), yolk } \\
(0.6587 \mathrm{ppm}) \text { and whole egg }(0.5867 \mathrm{ppm}) \text { were quantified. The highest TBZ concentration } \\
(0.5260 \mathrm{ppm}) \text { as well as total TBZ residue on any day from day } 2 \text { to day } 9 \text { in the entire white } \\
\text { portion of egg were significantly }(P<0.01) \text { higher than those in the yolk. Egg white, yolk and } \\
\text { whole egg from the TBZ fed hens had residues at } 50.71 \text { to } 153.50,75.62 \text { to } 153.50 \text { and } 50.71 \\
\text { to } 153.50 \mathrm{~h} \text { after first feeding, respectively. The highest concentration TBZ residue in whole } \\
\text { egg is } 0.4308 \pm 0.0253 \text { ppm and cumulative residue is } 8.1886 \pm 6.5385 \text { ppm and also calculated } \\
\text { in microgram is useful to show as per the standard values. The work indicated that safe dose } \\
\text { and days to consume egg. Safe time/days can be reduced for consuming eggs after } \\
\text { administration of thiabendazole by using different types of decontamination techniques. }\end{array}$} & Article Info \\
\hline & rticle History: \\
\hline & Received : 09-07-2014 \\
\hline & : 21-09-2014 \\
\hline & $\begin{array}{l}\text { Accepted : 26-09 } \\
\text { Keywords: }\end{array}$ \\
\hline & Thiabendazole \\
\hline & lues \\
\hline & Yolk \\
\hline & \\
\hline & \\
\hline & ${ }^{*}$ Corresponding Author: \\
\hline & Mahadeva Naika \\
\hline & \\
\hline & \\
\hline
\end{tabular}

\section{INTRODUCTION}

Use of several veterinary drugs on food-producing animals, grown intensively by modern animal husbandry practices, is common to many countries (Mellon et al., 2001; Solomon et al., 2002; Wachtel et al., 2002; Goldman 2004 and Cam et al., 2009). Thiabendazole (TBZ), registered in many countries, is used as a broadspectrum anthelminthic agent to control parasitic infestations in animals. It is also used as antifungal as well as growth promoting agent on animals. Inappropriate use of veterinary drugs on animals as well as in feeds and foodstuffs has led to their increased residues in human food commodities like eggs in many countries including India (Schaellibaum 1990; Lidong 1992; Paige 1994; Reja-Sanche et al., 1995 and Okerman et al., 2001).

As a direct hazard, chronic and acute toxicities such as teratogenesis, carcinogenicity, liver hypertrophy, thyroid hyperplasia, immuno-suppression and decreased foetal as well as maternal body weight have been associated with varying exposures to benzimidazoles including TBZ as a major compound. The most concern for indirect hazard from the use of antibiotics in animal husbandry is the development of drug-resistant pathogens in food animals (Kulshrestha 1990; Brady et al., 1993;
Bordas et al., 1997; Gogus et al., 2000 and Wrigley et al., 2006), which in turn, may lead to antibiotic-resistant pathogen in animal-derived foodstuffs and human beings (Willis et al., 1999; Rajashekara et al., 2000; Swartz, 2002; Schlegelova, 2002 and Horby et al., 2003).

Distribution of veterinary drug residues and their dissipation from various parts of animal's body, depending upon type of drugs, animal, organ, meat portion, milk, egg etc., may give rise to their detectable residue levels (Takahashi et al., 1991; Donoghue et al., 1999; Kuehn et al., 2000; Cornelis et al., 2000 and Roudaut et al., 2000). Glomerullar filtration and tubular secretion are the major routes of administration of TBZ, faecal elimination through enterohepatic recycling and bone sequestration are the secondary routes for the elimination of administered TBZ from animal body (Bai et al., 2010). Conversely, oral administration of TBZ to sheep, cattle, goats, dogs and humans results rapid absorption from the Gl tract, and almost all the entire quantity is recovered from urine and faeces. The hydroxylation of the benzimidazole ring at the 5-position to form 5-OH TBZ and subsequent conjugation to form the glucuronide and sulfate are the major metabolic steps. In a study an oral administration of 3.19 


\section{Mahadeva Naik and Farhath Khanum}

mg of $\left[{ }^{14} \mathrm{C}\right] \mathrm{TBZ}$ daily to laying hens for 10 consecutive days showed an average recovery of $96.6 \%$ of the total administered dose, and about $99.6 \%$ of this recovered dose was found in the excreta, in the form of both unconjugated $(3.4 \mathrm{mg} / \mathrm{kg})$ and conjugated $(4.4 \mathrm{mg} / \mathrm{kg}) 5$ OH TBZ (Halls et al., 1991a; Chukwudebe et al., 1994 and Bai et al., 2010). Cumulatively, the total residues found in the tissues and eggs accounted for about $0.4 \%$ or less of the ${ }^{14} \mathrm{C}$. The total residues in eggs attained a level of about $0.1 \mathrm{mg} / \mathrm{kg}$ by day 2 and remained relatively unchanged throughout the next 8 days. The residues in tissues and eggs consisted mainly of unconjugated $5-\mathrm{OH}$ TBZ, unmetabolized TBZ and benzimidazole at maximum concentrations, in the kidneys, of $0.4,0.11$ and 0.12 $\mathrm{mg} / \mathrm{kg}$ respectively. In an animal transfer study, chickens (males and females) treated continuously for 7 weeks with TBZ at levels corresponding to 2, 20, 200 and 2000 ppm in the feed (Yang et al., 2011), showed the sum of TBZ and $5-\mathrm{OH}$ TBZ including its conjugate as $20-28 \mathrm{ppb}$ in fat taken from different body parts, $17-23 \mathrm{ppb}$ in a 1:1 mixture of breast and leg meat, and $60-80$ ppb in liver at the 20 $\mathrm{mg} / \mathrm{kg}$ feed level. Neither TBZ nor its related residues are likely to persist in milk, eggs or edible tissues because of their relatively low concentrations and rapid elimination. Present study was undertaken to find out the accumulation and degradation levels of TBZ in layer chicken (BV 300) administered with a dose of $75 \mathrm{mg}$ per bird per day for 5 consecutive days.

\section{MATERIALS AND METHODS}

HPLC grade water filtered through $0.2 \mu \mathrm{m}$ (Qualigens Fine Chemicals, Glaxo-SmithKline Pharmaceuticals Ltd), HPLC grade acetonitrile and methanol (Ranbaxy Fine Chemicals Ltd, SAS Nagar, India), filtered through a 0.2 $\mu \mathrm{m}$ membrane) purchased from Sigma-Aldrich Corporation) were used. Mobile phase was prepared and filtered through $0.22 \mu \mathrm{m}$ Millipore Durapore solvent filters (disc, $47 \mathrm{~mm}, 9.6 \mathrm{~cm}^{2}$ filtration areas) under vacuum with Millipore All-glass Filter unit, degassed. Analytical standard thiabendazole (Sigma-Aldrich) was dissolved in HPLC grade methanol to get 1000 ppm neat stock standard corrected to $100 \%$ purity and stored at $-18^{\circ} \mathrm{C}$ in epandorff vials for a maximum period of 1 week. Each time working standard solutions were prepared a fresh from the stock standard.

Layer Chicken: Eight (6 experimental and 2 control) numbers of 25 week old birds of strain BV 300 were randomly selected from a flock of 9740 birds from a commercial local poultry farm for TBZ feeding trial. The birds were fed with a diet as in Table 1.

Table 1: Diet composition

\begin{tabular}{lc}
\hline Feed Ingredients & $\begin{array}{c}\text { Quantity, } \\
\% \text { w/w }\end{array}$ \\
\hline Broken maize & 50 \\
Deoiled sunflower cake & 15 \\
Deoiled soya cake & 15 \\
Broken rice & 9 \\
Shell grits & 7.9 \\
Mineral mixture & 2.5 \\
Common salt, iodised at 30 ppm & 0.4 \\
Vitamin premixes (A, D, E, K, B complex & 0.05 \\
and probiotics) & 0.05 \\
Liver stimulant (hepatocare) & 0.05 \\
Toxin binder (UTPP) & 0.05 \\
Lysine and methionine (Biometh) & \\
\hline
\end{tabular}

Sci. Technol. Arts Res. J., July-Sep 2014, 3(3): 70-74

TBZ Administration: Thiabendazole (MW 201.25, >99\% purity) was procured from Sigma-Aldrich Inc, St. Louis, USA. TBZ solution/suspension of $25000 \mathrm{ppm}$ was prepared in distilled water, $3 \mathrm{ml}$ of which was used to administer each of 6 experimental birds with a single oral dose of $75 \mathrm{mg}$ TBZ per bird per day for 5 consecutive days.

Design of Experiment and Statistical Analysis: Each of 6 experimental and 2 control birds were individually housed in a medium mesh (2 cm square) Gl cage of 22 " 20 " $\times 20 "(\mathrm{LWW} \times \mathrm{H})$, and cages were randomly placed in a properly lit and ventilated animal experiment room. Birds were administered with TBZ at $110^{\prime}$ clock daily for 5 consecutive days. Live bird weight at the time of feeding, egg weight and laying time were recorded. Wherever egg laying time was not noticed actually, especially if at night, it was calculated by extrapolation from the previously or subsequently noted actual laying times. Eggs were collected from the first day to the day of non-detectable residue level, weighed and immediately stored at $5-6^{\circ} \mathrm{C}$. Each day's eggs were broken, separated into the albumin and the yolk, which were weighed and used for analysis of TBZ residue. Once the residue level reached the nondetectable levels in egg, the birds were slaughtered and residue levels in breast meat, leg meat and liver were analyzed for TBZ residue by HPLC- fluorescence detector (Arenas et al., 1995).

Bird Sacrifice: Bird was sacrificed once the TBZ residue in the eggs reached below detection limit no need for monitoring the day now.

\section{RESULTS AND DISCUSSION}

Accumulation of TBZ in albumin and yolk of eggs obtained from administered layer hens from after first day of TBZ feeding to till non-detectable days $\left(11^{\text {th }}\right.$ day) and from scarified hens at the end of experiment were presented in the form of both individual concentration as well as total residue levels. Subsequently quantified the TBZ levels in eggs on different times (hours) after the administration were shown table 2.

TBZ residue concentration (ppm) as well as total TBZ residue in entire portion of white, yolk or whole egg (white + yolk) with respect to the mean time after first TBZ administration were shown in table 2. TBZ residue was not detected in egg white and yolk on day 1 and day 11 after a mean time of 1.96 and $252.58 \mathrm{~h}$ from first feeding, respectively, and non-detectable residue levels were considered as nil residues for statistical analysis and interpretation. In case of egg white, TBZ residues concentration of $0.0888 \mathrm{ppm}$ (i.e., $2.6203 \mu \mathrm{g}$ total residue in the entire white portion) appeared on day 2 (after mean time of $25.87 \mathrm{~h}$ from first feeding), reached a maximum concentration level of $0.5260 \mathrm{ppm}$ (i.e., $15.5925 \mu \mathrm{g}$ total residue) on day 6 (after $127.54 \mathrm{~h}$ from first feeding) and declined thereafter to $0.0108 \mathrm{ppm}$ concentration level (i.e., $0.2996 \mathrm{ug}$ total residue) on day 10 (after $227.62 \mathrm{~h}$ from first feeding) before reaching non-detectable level on day 11. Similarly for egg yolk, TBZ residues concentration of $0.0215 \mathrm{ppm}$ (i.e., $0.2964 \mathrm{ug}$ total residue in the entire yolk portion) appeared on day 2 (after mean time of $25.87 \mathrm{~h}$ from first feeding), reached a maximum concentration level of $0.2157 \mathrm{ppm}$ (i.e., $2.8544 \mu \mathrm{g}$ total residue) on day 6 (after $127.54 \mathrm{~h}$ from first feeding) and declined thereafter to $0.0144 \mathrm{ppm}$ concentration level (i.e., 0.1899 $\mu \mathrm{g}$ total residue) on day 10 (after $227.62 \mathrm{~h}$ from first 
Table 2: TBZ residue in eggs and their components $(n=6)$

\begin{tabular}{|c|c|c|c|c|}
\hline \multirow{2}{*}{$\begin{array}{l}\text { Day and Time of } \\
\text { Laying from First } \\
\text { Feeding }\end{array}$} & \multicolumn{3}{|c|}{ TBZ Concentration (TC), ppm } & \multirow{2}{*}{$\begin{array}{c}\text { TBZ Concentration } \\
\text { Ratio (TCR) White/ } \\
\text { Yolk (TCW/TCY) }\end{array}$} \\
\hline & $\begin{array}{l}\text { Egg White } \\
\text { (TCW) }\end{array}$ & $\begin{array}{l}\text { Egg Yolk } \\
\text { (TCY) }\end{array}$ & $\begin{array}{c}\text { Whole Egg } \\
\text { (TCT) }\end{array}$ & \\
\hline Day $1,1.96 \pm 1.17 \mathrm{~h}$ & $0.0 \pm 0.0^{\mathrm{A}}$ & $0.0 \pm 0.0^{\mathrm{A}}$ & $0.0 \pm 0.0^{\mathrm{A}}$ & - \\
\hline Day $2,25.87 \pm 0.66 \mathrm{~h}$ & $0.0888 \pm 0.0176^{\mathrm{FG}}$ & $0.0215 \pm 0.0064^{C D}$ & $0.0675 \pm 0.0101^{\mathrm{EF}}$ & $4.6323 \pm 2.1717^{\mathrm{de}}$ \\
\hline Day $3,50.71 \pm 1.16 \mathrm{~h}$ & $0.3197 \pm 0.0380^{\mathrm{LM}}$ & $0.0541 \pm 0.0139^{\mathrm{E}}$ & $0.2314 \pm 0.0254^{\mathrm{K}}$ & $6.2644 \pm 1.9614^{\mathrm{e}}$ \\
\hline Day $4,75.62 \pm 0.93 \mathrm{~h}$ & $0.3859 \pm 0.0438^{\mathrm{MN}}$ & $0.1194 \pm 0.0188^{\mathrm{GH}}$ & $0.3025 \pm 0.0318^{L}$ & $3.2871 \pm 0.5345^{d}$ \\
\hline Day $5,101.67 \pm 1.02 \mathrm{~h}$ & $0.4801 \pm 0.0370^{\mathrm{OP}}$ & $0.1906 \pm 0.0231^{\mathrm{IJK}}$ & $0.3944 \pm 0.0310^{\mathrm{N}}$ & $2.5405 \pm 0.2608^{d}$ \\
\hline Day $6,127.54 \pm 1.62$ h & $0.5260 \pm 0.0360^{P}$ & $0.2157 \pm 0.0290^{\mathrm{JK}}$ & $0.4308 \pm 0.0253^{\mathrm{NO}}$ & $2.4871 \pm 0.4799^{d}$ \\
\hline Day $7,153.50 \pm 2.35 \mathrm{~h}$ & $0.1853 \pm 0.0288^{\mathrm{IJK}}$ & $0.1439 \pm 0.0310^{\mathrm{HI}}$ & $0.1724 \pm 0.0261^{\mathrm{IJ}}$ & $1.3171 \pm 0.2429^{c}$ \\
\hline Day $8,177.62 \pm 3.35 \mathrm{~h}$ & $0.0965 \pm 0.0168^{G}$ & $0.0697 \pm 0.0164^{\mathrm{EFG}}$ & $0.0886 \pm 0.0161^{\mathrm{FG}}$ & $1.4117 \pm 0.2142^{\mathrm{c}}$ \\
\hline Day $9,201.37 \pm 4.89$ h, & $0.0157 \pm 0.0051^{\mathrm{BC}}$ & $0.0520 \pm 0.0105^{\mathrm{E}}$ & $0.0267 \pm 0.0046^{\mathrm{D}}$ & $0.3123 \pm 0.1199^{a}$ \\
\hline Day $10,227.62 \pm 3.90 \mathrm{~h}$ & $0.0108 \pm 0.0024^{B}$ & $0.0144 \pm 0.0029^{B C}$ & $0.0120 \pm 0.0024^{B}$ & $0.7559 \pm 0.1021^{\mathrm{b}}$ \\
\hline Day $11,252.58 \pm 4.58 \mathrm{~h}$ & $0.0 \pm 0.0^{\mathrm{A}}$ & $0.0 \pm 0.0^{\mathrm{A}}$ & $0.0 \pm 0.0^{\mathrm{A}}$ & - \\
\hline $\begin{array}{c}\text { Grand Mean, } \\
\text { day } 2 \text { to } 10, N=6 \times 9\end{array}$ & $0.2343 \pm 0.1910^{\prime \prime}$ & $0.0979 \pm 0.0717^{\prime}$ & $0.1918 \pm 0.1511^{\prime \prime}$ & $2.5565 \pm 2.0591$ \\
\hline
\end{tabular}

Mean \pm SD $(n=6)$ values of TBZ concentrations $(T C)$, carrying different superscripts $A, B, C, \ldots .$. vary significantly $(P<0.01)$ or $1,2,3, \ldots$ vary significantly $(P<0.05)$. Mean $\pm S D(n=6)$ values of TBZ concentration ratio $(\mathrm{TCR}=\mathrm{TCW} / \mathrm{TCY})$ in a particular column, carrying different superscripts $\mathrm{a}, \mathrm{b}, \mathrm{c}, \ldots \ldots$ vary significantly $(P<0.01)$. Grand mean $\pm \mathrm{SD}(\mathrm{N}=6 \mathrm{XX})$ values of TBZ concentrations in a particular row , carrying different superscripts I, II, III, ..... vary significantly $(P<0.05)$.

feeding) before reaching non-detectable level on day 11. It showed that TBZ residue in the egg white appeared faster and at a significantly $(P<0.01)$ higher concentration level than that in the yolk table 3 (Himanish Das et al., 2008).

Furthermore, TBZ residue dissipated faster from the white than from the yolk due to degradation/dissipation of thiabendazole. The highest TBZ concentration $(0.5260$ ppm) as well as total TBZ residue on any day from day 2 to day 9 in the entire white portion were significantly $(P<0.01)$ higher than those in the yolk (table 2 and 3$)$. The egg white, the yolk and the whole egg contained the TBZ residue greater than the USEPA maximum residue limit (MRL) of $0.100 \mathrm{ppm}$ in egg for TBZ (including 5-OH TBZ) on day 3 to day 7 ( 50.71 to $153.50 \mathrm{~h}$ ), on day 4 to day 7 ( 50.71 to $153.50 \mathrm{~h}$ ) and day 3 to day 7 (50.71 to $153.50 \mathrm{~h}$ ) after first feeding, respectively Rey-Grobellet et al., (1996). In other words, the egg white, the yolk and the whole egg from the hens, fed with a dose of $75 \mathrm{mg}$ TBZ per day per bird for 5 days, had violative residues on day 3 to day 7 (50.71 to $153.50 \mathrm{~h}$ ), on day 4 to day 7 (50.71 to $153.50 \mathrm{~h})$ and day 3 to day 7 (50.71 to $153.50 \mathrm{~h})$ after first feeding, respectively table 2 . Mean weights of whole egg, egg without shell, white and yolk with respect to mean time after first TBZ administration. No significant effect due to the drug administration on birds' live weight, laying time and egg weights during the entire experiment was observed.

Table 3: TBZ residue in eggs and their components

\begin{tabular}{|c|c|c|c|c|c|c|}
\hline \multirow{2}{*}{$\begin{array}{c}\text { Day and Time } \\
\text { of Laying } \\
\text { from First } \\
\text { Feeding }\end{array}$} & \multicolumn{3}{|c|}{ TBZ Residue Concentration, ppm } & \multicolumn{3}{|c|}{ TBZ Total Residue, $\mu \mathrm{g}$} \\
\hline & Egg White (WC) & Egg Yolk (YC) & $\begin{array}{c}\text { Whole Egg } \\
\text { without Shell } \\
\text { (TC) }\end{array}$ & Egg White (WQ) & Egg Yolk (YQ) & $\begin{array}{c}\text { Whole Egg } \\
\text { without Shell } \\
\text { (TQ) }\end{array}$ \\
\hline $\begin{array}{c}\text { Day } 1 \\
1.96 \pm 1.17 \mathrm{~h}\end{array}$ & $0.0 \pm 0.0^{A}$ & $0.0 \pm 0.0^{A}$ & $0.0 \pm 0.0^{A}$ & $0.0 \pm 0.0^{\mathrm{a}}$ & $0.0 \pm 0.0^{\mathrm{a}}$ & $0.0 \pm 0.0^{\mathrm{a}}$ \\
\hline $\begin{array}{c}\text { Day 2, } \\
25.87 \pm 0.66 \mathrm{~h}\end{array}$ & $0.0888 \pm 0.0176^{F G}$ & $0.0215 \pm 0.0064^{\mathrm{CD}}$ & $0.0675 \pm 0.0101^{\mathrm{EF}}$ & $2.6203 \pm 0.5041^{\mathrm{ij}}$ & $0.2964 \pm 0.0917^{b c}$ & $2.9166 \pm 0.4196^{i j}$ \\
\hline $\begin{array}{c}\text { Day 3, } \\
50.71 \pm 1.16 \mathrm{~h}\end{array}$ & $0.3197 \pm 0.0380^{\mathrm{LM}}$ & $0.0541 \pm 0.0139^{\mathrm{E}}$ & $0.2314 \pm 0.0254^{K}$ & $9.3450 \pm 1.3531^{1 \mathrm{~m}}$ & $0.7345 \pm 0.2203^{\text {def }}$ & $10.0795 \pm 1.4755^{\mathrm{mn}}$ \\
\hline $\begin{array}{c}\text { Day 4, } \\
75.62 \pm 0.93 \mathrm{~h}\end{array}$ & $0.3859 \pm 0.0438^{\mathrm{MN}}$ & $0.1194 \pm 0.0188^{\mathrm{GH}}$ & $0.3025 \pm 0.0318^{\mathrm{L}}$ & $10.946 \pm 1.1419^{\mathrm{mn}}$ & $1.5548 \pm 0.3131^{\mathrm{gh}}$ & $12.5008 \pm 1.3335^{\text {no }}$ \\
\hline $\begin{array}{c}\text { Day 5, } \\
101.67 \pm 1.02 \mathrm{~h}\end{array}$ & $0.4801 \pm 0.0370^{\mathrm{OP}}$ & $0.1906 \pm 0.0231^{\mathrm{IJK}}$ & $0.3944 \pm 0.0310^{\mathrm{N}}$ & $14.7666 \pm 1.3693^{o p}$ & $2.5403 \pm 0.4616^{\mathrm{ij}}$ & $17.3070 \pm 1.6610^{\mathrm{pq}}$ \\
\hline $\begin{array}{c}\text { Day 6, } \\
127.54 \pm 1.62 \mathrm{~h}\end{array}$ & $0.5260 \pm 0.0360^{P}$ & $0.2157 \pm 0.0290^{\mathrm{JK}}$ & $0.4308 \pm 0.0253^{\mathrm{NO}}$ & $15.5925 \pm 0.8510^{p}$ & $2.8544 \pm 0.4573^{j}$ & $18.4470 \pm 0.9598^{q}$ \\
\hline $\begin{array}{c}\text { Day 7, } \\
153.50 \pm 2.35 \text { h }\end{array}$ & $0.1853 \pm 0.0288^{\mathrm{IJK}}$ & $0.1439 \pm 0.0310^{\mathrm{HI}}$ & $0.1724 \pm 0.0261^{1 \mathrm{~J}}$ & $5.3241 \pm 0.9303^{k}$ & $1.8807 \pm 0.4484^{h}$ & $7.2048 \pm 1.2045^{\mathrm{kl}}$ \\
\hline $\begin{array}{c}\text { Day 8, } \\
177.62 \pm 3.35 \text { h }\end{array}$ & $0.0965 \pm 0.0168^{G}$ & $0.0697 \pm 0.0164^{\mathrm{EFG}}$ & $0.0886 \pm 0.0161^{\mathrm{FG}}$ & $2.7911 \pm 0.6085^{\mathrm{ij}}$ & $0.8473 \pm 0.2246^{\mathrm{ef}}$ & $3.6387 \pm 0.8009^{j}$ \\
\hline $\begin{array}{c}\text { Day } 9 \\
201.37 \pm 4.89 \text { h }\end{array}$ & $0.0157 \pm 0.0051^{\mathrm{BC}}$ & $0.0520 \pm 0.0105^{\mathrm{E}}$ & $0.0267 \pm 0.0046^{D}$ & $0.4615 \pm 0.1710^{\text {cd }}$ & $0.6521 \pm 0.1085^{\mathrm{de}}$ & $1.1136 \pm 0.2005^{\mathrm{fg}}$ \\
\hline $\begin{array}{c}\text { Day 10, } \\
227.62 \pm 3.90 \mathrm{~h}\end{array}$ & $0.0108 \pm 0.0024^{B}$ & $0.0144 \pm 0.0029^{B C}$ & $0.0120 \pm 0.0024^{B}$ & $0.2996 \pm 0.0812^{\mathrm{bc}}$ & $0.1899 \pm 0.0517^{b}$ & $0.4894 \pm 0.1267^{c d}$ \\
\hline $\begin{array}{c}\text { Day 11, } \\
252.58 \pm 4.58 \mathrm{~h}\end{array}$ & $0.0 \pm 0.0^{A}$ & $0.0 \pm 0.0^{\mathrm{A}}$ & $0.0 \pm 0.0^{A}$ & $0.0 \pm 0.0^{\mathrm{a}}$ & $0.0 \pm 0.0^{\mathrm{a}}$ & $0.0 \pm 0.0^{\mathrm{a}}$ \\
\hline
\end{tabular}


Table 4: TBZ residue in eggs and their components

\begin{tabular}{|c|c|c|c|}
\hline & \multicolumn{3}{|c|}{ TBZ Residue $t$} \\
\hline & White & Yolk & Whole Egg \\
\hline Highest residue concentration (ppm), $n=6$ & $0.5260 \pm 0.0360^{\mathrm{c3}}$ & $0.2157 \pm 0.0290^{\mathrm{a} 1}$ & $0.7308 \pm 0.0253^{\mathrm{b} 2}$ \\
\hline Highest total residue $(\mu \mathrm{g}), \mathrm{n}=6$ & $15.5925 \pm 0.8510^{\mathrm{C}}$ & $2.8544 \pm 0.4573^{\mathrm{a}}$ & $18.4470 \pm 0.9598^{d}$ \\
\hline Cumulative residue Mean $\pm S D(\mu g), n=60$ & $6.9052 \pm 5.7154^{\mathrm{B}}$ & $1.2834 \pm 0.9659^{A}$ & $8.1886 \pm 6.5385^{\mathrm{B}}$ \\
\hline Cumulative residue of 54 eggs (TBZ) (ug) & 372.88 & 69.30 & 442.18 \\
\hline Cumulative residue of 54 eggs (TBZ) (as \% of drug fed) & $0.0994 \%$ & $0.0185 \%$ & $0.1179 \%$ \\
\hline
\end{tabular}

\section{CONCLUSIONS}

No significant effect due to TBZ administration was observed on birds' live weight, laying time and egg weight during the experiment. Upon TBZ administration, the highest residue $(0.4308 \pm 0.0253 \mathrm{ppm})$, the < MRL $(0.1$ $\mathrm{ppm})$ residue $(0.0886 \pm 0.0161 \mathrm{ppm})$ as well as the $<$ LOD residue concentrations in eggs were observed in the mean time of $127.54,177.62$ and $252.58 \mathrm{~h}$ after first feeding, respectively. The highest TBZ concentration ( $0.5260 \mathrm{ppm})$ as well as total TBZ residue on any day from day 2 to day 9 in the entire white portion were significantly $(P<0.01)$ higher than those in the yolk (table 2 and 3 ). Egg white, yolk and whole egg from the TBZ treated hens had violation residues on 50.71 to 153.50 , 75.62 to 153.50 and 50.71 to $153.50 \mathrm{~h}$ after first feeding, respectively. The highest concentration of TBZ residue in whole egg was observed $0.4308 \pm 0.0253 \mathrm{ppm}$ and the cumulative residue $8.1886 \pm 6.5385 \mathrm{ppm}$, and also calculated in microgram is useful to show as per the standard values (table 4)

\section{ACKNOWLEDGEMENTS}

We are thankful to Dr. H.V Batra, Director, Defence Food Research Laboratory Mysore for kind permission to publish this paper.

\section{REFERENCES}

Arenas, R.V. and Johnson, N.A. (1995). Liquid Chromatographic Fluorescence Method for Multiresidue Determination of Thiabendazole and 5-Hydroxy thiabendazolei in Milk. Journal of Association of Official Analytical Chemistry International 78(3): 642-646.

Bai, X., Bai, F., Zhang, K., Lv, X., Qin, Y., Li, Y., Bai, S. and Lin, S. (2010). Tissue deposition and residue depletion in laying hens exposed to melamine-contaminated diets, Journal Agriculture. Food Chemistry 58(9): 5414-5420.

Bordas, A.C., Brady, M.S., Siewierski, M. and Katz, S.E. (1997). In vitro enhancement of antibiotic resistance development interaction of residue levels of pesticides and antibiotics. Journal Food Protection 60: 531-536.

Brady, M.S., White, N and Katz S.E. (1993). Resistance development potential of antibiotic/antimicrobial residue levels designated as 'safe levels'. Journal Food Protection 56: 229-233.

Cam, Y., Koç A.N., Silici, S., Günes, V., Buldu, H., Onmaz, A.C. and Kasap, F. (2009). Treatment of dermatophytosis in young cattle with propolis and Whitfield's ointment. Veterinary Reclination 11(2): 57-58.

Chukwudebe, A.C., Wislocki, P.G., Sanson, D.R., Halls, T.D. J. and Van den Heuvel, W.J.A. (1994). Metabolism of thiabendazole in laying hen and lactating goats. Journal of Agriculture Food Chemistry 42: 2964-2969.
Cornelis, A. Kan. and Michael Petz. (2000). Residues of veterinary drugs in eggs and their distribution between yolk and white. Journal of Agriculture Food Chemistry 48 (12): 6397-6403.

Gogus, A., Basol, M.S. and Sahin, E. (2000). Effect of various antibiotic applications on some chemical, microbial and physical properties of lamb. Journal of Food Quality 23 (2): 217-224.

Goldman, E. (2004). Microbial risk assessment. Antibiotic abuse in animal agriculture: Exacerbating drug resistance in human pathogens. Human Ecological Risk Assessment 10: 121-134.

Halls, T.D.J., Avor, K. and Sanson, D.R. (1991a). Metabolism of $\left[{ }^{14} \mathrm{C}\right]$ thiabendazole (TBZ) in poultry. Report No. 37728. $A B C$ Laboratories; USA.

Himanish Das. and Bawa, A.B. (2008) Distribution of oxytetracycline residues in eggs from orally administered hens. International Journal of Food Safety, Nutrition and Public Health 1: 167-180

Horby, P.W., O'Brien, S.J., Adak, G.K., Graham, C., Hawker, J.I., Hunter, P., and Lane, C. (2003). A national outbreak of multi-resistant Salmonella enterica serovar Typhimurium definitive phage type (DT) 104 associated with consumption of lettuce. Epidemiology and Infection 130(2): 169-178.

Kuehn, M., Wegmann, S., Kobe, A. and Fries, R. (2000). Tetracycline residues in bones of slaughtered animals. Food Control 11(3): 175-180.

Kulshrestha, S.B. (1990). Prevalence of enteropaogenic serogroups of $E$ coli in milk products samples from Bareilly and their multiple drug resistance. Indian Journal Dairy Science 43: 373-378.

Lidong, F. (1992). Adulteration of farm milk in China. Food Lab News 8: 39-42.

Mellon, M., Benbrook, C. and Benbrook, K. L. (2001). Hogging it: estimates of antimicrobial abuse in livestock. Union of Concerned Scientists, Cambridge, MA, USA (http://www.ucsusa.org/food_and_environment/antibiotic. resistance)

Nagy, J., Sokol, J., Turek, P., Korimova, L. and Rozanska, H. (1997). Residues of oxytetracycline in egg white and yolk after medication of laying hens. Bulletin Veterinary Institute of Pulawy 41: 141-147.

Okerman, L., Croubels, S., Baere, S-de., Hoof, J-van., Backer, P-de and Brabander, H-de. (2001). Inhibition tests for detection and presumptive identification of tetracyclines, beta-lactam antibiotics and quinolones in poultry meat. Food Additives and Contamination 18: 385393.

Paige, J.C. (1994). Analysis of tissue residues. Food Drug Adultration Veternary 9: 4-6. 


\section{Mahadeva Naik and Farhath Khanum}

Rajashekara, G., Haverly, E., Halvorson, D.A., Ferris, K.E., Lauer, D.C., and Nagaraja, K.V. (2000). Multidrugresistant Salmonella Typhimurium DT104 in poultry. Journal of Food Protection 63: 155-161.

Rey-Grobellet X, Eeckhoutte C Sutra J.F, Alvinerie M, and Galtier P. (1996). Major involvement of rabbit liver cytochrome P4501A in thiabendazole 5-hydroxylation. Xenobiotica 26 765-778.

Reja-Sanchez, A., Ruiz-de-Castaneda-Sempere, A., Santiago-Laguna, D. and Cano-Marin, M. (1995). Understanding of the health risk associated with presence of antibiotics in cow milk. Codex Alimentary 263: 59-66.

Schaellibaum, M. (1990). Antibiotic therapy and residues in delivered milk. Swiss Veterinary 7-9.

Schlegelova, J. (2002). Prevalence of and resistance to antimicrobial drugs in selected microbial species isolated from bulk milk samples. Journal of Veterinary Medicine 49: $216-225$

Solomon, E.B., Yaron, S. and Mathews, K.R. (2002). Transmission of Escherichia coli O157:H7 from contaminated manure and irrigation water to lettuce plant tissue and its subsequent internalization. Applied Environment Microbiology 68: 397-400.
Sci. Technol. Arts Res. J., July-Sep 2014, 3(3): 70-74

Swartz, M.N. (2002). Human diseases caused by food borne pathogens of animal origin. Clinical Infections Diseases 34(3): S111-122.

Takahashi, Y., Said, A.A., Hashizume, M. and Kido, Y. (1991). Sulfadimethoxine residue in broiler-chicken skin. Journal of Veterinary Medical Science 53: 33-36.

Volkov, I.B. and Kovalev, V.F. (1994). Residual quantity of chemical substances in products of animal origin. Veterinary Moscow 4: 42-44.

Wachtel, M.R., Whitehand, L.C. and Mandrel, R.E. (2002). Assosiation of Escherichia coli O157:H7 with preharvest leaf lettuce upon exposure to contaminated irrigation water. Journal of Food Protection 65: 18-25.

Willis, C., Booth, H., Westacott, S. and Hawtin, P. (1999). Detection of antibacterial agents in warm water prawns. Public Health 2: 210-215.

Wrigley, J., McArthur, M., McKenna, P.B. and Mariadass, B. (2006). Resistance to a triple combination of broadspectrum anthelmintics in naturally-acquired Ostertagia circumcincta infections in sheep. New Zealand Veterinary Journal 4(1): 47-49

Yang, T., Huangfu, W.G., and Wu, Y.L. (2011). Melamine residues in eggs of laying hens exposed to melaminecontaminated feed. Poultry Science 90(3): 701-704. 